Pavel Kryazhev, Ph.D. (Pedagogical Sciences), Mykola Gogol State University of Nizhyn

\title{
MISSION OF PORTUGUESE NAVIGATOR DUARTE PACHECO PEREIRA ON THE EVE OF BRAZIL DISCOVERY
}

\begin{abstract}
In the article we examine the mission of a Portuguese navigator Duarte Pacheco Pereira on the eve of Brazil discovery by the squadron of major-captain Pedro Alvares Cabral in 1500. We emphasized on the extract of Pereira guide-book which narrates about order of portuguese monarch Manuel I to dispatch the squadron of indicated navigator for realization reconnaissance mission towards western land behind the Atlantic ocean. Within the context of hypothesis about the voyage of Pereira squadron towards coasts of Brazil we mention the existence of the magister Joao's letter which tells about the ancient world map of the Portuguese navigator Pero Vaz da Cunha. This map represented new land which has been discovered by the squadron of major-captain Cabral. Also the map represented the western coast of Africa. We draw attention to the circumstance that this lost world map could clarify politics of the Portuguese monarch Joao II concerning the signing of Tordesillas treaty with the kings of Castilla and Aragon in 1494. We determined that on the eve of the abovementioned treaty signing the Portuguese monarch had protected his sovereign jurisdiction on the lands which would be discovered on the territory of the South Atlantic Ocean water zone. This fact is confirmed by the signing of Toledo treaty in 1480.

We as well emphasize that Pereira had realized the reconnaissance of the Portuguese sector of the Atlantic Ocean towards Southwest direction behind the demarcation meridian in 1498. This act has been provoked by the necessity to ensure safety of the Portuguese sea navigation towards India.
\end{abstract}

Key words: geographic discoveries, Portugal, Brazil, Toledo treaty, Tordesillas treaty.

УДК 94(72):330.3+330.5+332.05

http://doi.org/10.17721/2521-1706.2017.03.223-232

Тетяна Перга

кандидат історичних наук, старший науковий співробітник

ДУ «Інститут всесвітньої історії НАН України», м.Київ

\section{ОСОБЛИВОСТІ СОЦАЛЬНО-ЕКОНОМІЧНОГО РОЗВИТКУ МЕКСИКИ У 40-70-Х РР. ХХ СТОЛІТТЯ}

\begin{abstract}
Анотація. Досліджується соціальна та економічна політика Мексики 1940-1970-х рр. Проаналізовано передумови економічного зростання Мексики, щуо почали формуватися ще в 1930-х - 1940-х рр., зокрема: аграрна та освітня реформи, націоналізачія найважливіших галузей промисловості та формування державного сектору, розширення експорту під час Другої світової війни. Розкрито причини прийняття та головні напрями політики імпортозамінної індустріалізації, серед яких: заохочення начіональних приватних капіталовкладень, захист їх від іноземних конкурентів; розширення державного сектора в промисловості шляхом націоналізаціі окремих підприємств $i$ галузей, будівництва державних підприємств; збільшення державного фінансування $i$ кредитування промисловості. Проаналізовано позитивні результати розвитку Мексики у 1940-1970-х рр.: високі темпи економічного зростання, стабільність національної валюти, низька інфлячія, розширення середнього класу, реалізація багатьох інфраструктурних та соиіальних проектів. Доведено, щзо не дивлячись на помітні короткострокові успіхи, обрана урядом Мексики стратегія
\end{abstract}


розвитку мала низку «побічних ефектів», які призвели до гальмування у наступні роки темпів економічного зростання, загострення сочіальної поляризації, надмірної залежності від зовнішнього фінансування. Це стало одним із чинників кризи початку 1980-х $\mathrm{pp}$.

Ключові слова: Мексика, імпортозамінна індустріалізація, «мексиканізація» економіки, економічне зростання.

На сучасній міжнародній арені Мексика займає особливе місце. Як одна 3 найбільших та найрозвиненіших країн Латинської Америки, що має другу за величиною економіку в регіоні, вона не одне десятиліття привертає увагу дослідників. Вирішення складних проблем перехідного періоду України актуалізує необхідність вивчення досвіду соціально-економічних перетворень різних країн світу, у тому числі - Мексики.

Особливостям соціально-економічного та політичного розвитку країни присвячена низка наукових праць як закордонних, так і вітчизняних фахівців. Ще в 1967 р. вийшла другом монографія А.Ф. Шульговського «Мексика на крутому повороті історії» [1], яка започаткувала в радянській історичній науці традицію вивчення моделі економічного розвитку країни. В Академії Наук СРСР (у рамках Інституту Латинської Америки) сформувалась радянська наукова школа мексиканістики, представники якої досліджували економічні, соціальні та політичні аспекти розвитку країни. Варто вказати на здобутки таких науковців, як В.С. Ковальов («Соціально-політичні перетворення в Мексиці» (1970р.) [2], «Аграрна реформа в Мексиці» (1980р.) [3], Т.В. Саприкову-Самінську, Ю.Г. Онуфрієва, Ю.Ф.Погорелова («Мексика: тенденції політичного і соціальноекономічного розвитку», 1983 р.) [4], Ю.І. Візгунову («Робітничий клас та визвольний рух Мексики 60-80-ті рр.» (1989 р.) [5] та інших фахівців. Значний доробок у дослідження проблеми мексиканського капіталізму, його генезису й еволюції зробив А.Ф.Шульговський, який є автором таких фундаментальних праць, як: «Мексика. Політика. Економіка, Культура» (1968 р.) [6], «Мексика: капіталізм і суспільство: протиріччя розвитку» (1990р.) [7].

Традиції цієї школи були продовжені науковцями Російської Академії Наук. До нової генерації вчених, які займаються проблематикою Мексики, можна віднести В.М.Давидова, А.В.Бобровникова А.В., А.Н.Боровкова, І.К.Шереметьєва, П.П.Яковлєва, А.А.Тепермана та ін. Їх наукові інтереси сфокусовані на моделі розвитку Мексики останньої третини XX ст. - початку XXI ст. Серед колективних монографій, що заслуговують на окрему увагу, вкажемо на роботу А.Н. Боровкова та І.К.Шереметьева «Мексика на новому повороті економічного і політичного розвитку» (1999 р.) [8], у якій здійснено аналіз передумов, причин і наслідків переходу країни до неоліберальної моделі розвитку й розглянуто кризу мексиканської політичної системи наприкінці XX ст. У монографії «Мексика: парадокси модернізації» (2013 р.), авторами якої є Бобровников А.В., Боровков А.Н, Візгунова Ю.І. та інші російські науковці [9], розглядається вплив на провідні тренди економічного і соціально-політичного розвитку країни початку XXI ст., проблем, які сформувались у Мексиці у попередні десятиліття.

У наукових працях європейських та американських фахівців, присвячених соціально-економічним перетворенням Мексики у 1940-1970-х рр., проаналізовано стратегію розвитку країни в цей період, коротко- та довгострокові наслідки іiі 
впровадження, здійснено порівняння ситуації 3 іншими латиноамериканськими країнами, які у другій половині XX ст. впроваджували політику імпортозаміщення (К. Баздреш, С.Леві, Т. Дж. Кехо, Феліпе Меза, П.Лейнс, Дж.Хейт, В.Корнеліус, Е.П.Стівкнс та ін.).

В останній чверті XX ст. у латиноамериканістиці почав розроблятися цивілізаційний підхід до дослідження історії країн регіону, включаючи Мексику (російські вчені Т. В. Гончарова, А. К. Стеценко, Я. Г. Шемякіна, А. Ф. Кофман, В. Б. Земськова, Ю. Н. Гирина, А.В.Бобровников, український науковець Космина B.Г.).

В українській історичній науці Мексика є однією з найменш вивчених країн. Соціальні та економічні аспекти пї розвитку розглянуті у деяких працях О.Д.Ковальової, Т. В. Семигіної, В.О. Шевчука, В.П. Газіна, А.С. Булатова К.С.Солонінко та ін. Багато дослідників фокусує увагу на участі Мексики в регіональних інтеграційних об'єднаннях, зокрема НАФТА, відповідно у їхніх працях здійснено побіжний огляд розвитку країни у другій половині XX ст. (Г.Д.Хоменко, Т.О.Кулініч, Т.Бессараб, Космина В.Г.,Н.М.Весела, Н.М.Комар та ін.)

Виходячи 3 вказаних обставин, автор вважає метою своєї роботи стислу наукову розвідку соціально-економічного розвитку Мексики у 1940-1970-х рр. Хронологічні рамки дослідження обгрунтовуються тим, що саме в цей період країна мала високі темпи економічного розвитку, що ставить завдання аналізу його передумов і головних факторів.

На початку дослідження зупинимось на передумовах економічного зростання Мексики, які почали формуватися ще в 1930-х - 1940-х рр. Перш за все, звернемо увагу на зменшення політичного напруження в країні, яке супроводжувало національні вибори під час і одразу після Мексиканської революції, що стало можливим унаслідок створення в 1929 р. єдиної домінуючої політичної сили «Національно-революційної партії» (пізніше перейменована на «Інституційнореволюційну партію» (IPП)), яка почала безроздільно керувати на всіх рівнях влади й охопила всі сегменти мексиканської еліти. Під їі керівництвом були здійснені важливі кроки, які мали серйозні наслідки для економічної політики країни після Другої світової війни.

Зокрема, під час президенства Ласаро Карденаса було розпочато аграрну реформу (вона тривала аж до початку 1970-х рр.), у результаті якої перерозподілено близько однієї третини всіх придатних для обробки земель в країні - 18,8 млн. га; ділянки отримали понад 2 млн. селянських сімей [10, С. 9]. IPП розглядала їі не лише як фактор збереження в суспільстві стабільності, а і як передумову успіху економічної політики уряду. У статті «Аграрна реформа в Мексиці» Ковальов Є.В. вказує, що ця реформа сприяла розвитку внутрішнього ринку, збільшенню виробництва сільськогосподарських товарів на експорт, зростаюча виручка від якого дозволила закуповувати більше машин і устаткування для індустріального розвитку країни [3, С. 68]. Для іiі підтримки держава здійснювала спеціальні заходи, що включили технічну i кредитну допомогу сільському господарству, підготовку кадрів, забезпечення машинами та інвентарем, систему державної підтримки цін на сільськогосподарські товари, агротехнічне сприяння 3 боку наукових організацій. Однак головним було звільнення мексиканського сільського господарства від пут латифундизму. У процесі аграрної 
реформи широкі маси селян-ехідатаріїв були залучені в товарно-грошові відносини. Поява в руках селянства певних коштів призвела до зростання попиту на промислові товари як споживчого, так i виробничого призначення, що послужило певним стимулом для розвитку національної промисловості. У статті «Соціально-політичні перетворення в Мексиці» вчений розвиває цю думку, наголошуючи, що розірвавши позаекономічну і економічну залежність селян від поміщиків, аграрна реформа різко збільшила мобільність населення, що також вплинуло на прискорення економічного розвитку, який охопив, у першу чергу, неосвоєні райони, що потребували припливу робітників [2, С. 41].

Важливу роль в економічному зростанні Мексики у повоєнний період відіграла націоналізація низки найважливіших галузей економіки та утворення значного за своїм розміром державного, по суті державно-капіталістичного, сектора економіки. Досліджуючи його особливості, I.К. Шереметьєв зазначає, що процес втручання держави в економіку Мексики розпочався у 1930-ті рр. та прийняло форму націоналізації майна іноземних монополій і створення на цій основі великих державних компаній, що стали основою державного сектора економіки [7,С.98]. Переломним етапом у його розвитку $є$ націоналізація нафтовидобувної i нафтопереробної промисловості. А.В.Бобровніков вказує на ключову роль у закладанні основ державно-капіталістичної моделі розвитку країни президента Ласаро Карденаса (1934-1940 рр.) [11, С. 40]. Своїм указом він надав уряду Мексики монополію на розвідку, видобуток і переробку нафти і природного газу, так само як і на дистрибуцію нафтопродуктів. У 1938 р. була створена державна компанія «Пемекс», яка отримала статус природної монополії в нафтовому сегменті. Націоналізація позбавила країну від іноземної залежності в цій вирішальній галузі енергетики.

На наш погляд, якщо аграрна реформа ліквідувала перепони на шляху прискореної індустріалізації, то формування державного сектора забезпечило реалізацію створених нею можливостей. Відповідно головним внеском державного сектора в промисловий розвиток країни $\epsilon$ мобілізація коштів для розвитку найбільш важливих i капіталомістких галузей народного господарства: нафтовидобутку і нафтопереробки, електроенергетики, дорожнього будівництва, транспорту і зв'язку.

Потрібно наголосити i на ролі освітньої реформи у створенні засад економічного зростання Мексики. Уряд зробив акцент на розширенні доступу до початкової освіти, в результаті чого 3 1920-х по 1940-ві рр. кількість жителів країни, що змогли їі отримати, зросла утричі. Здобуті навички сприяли підвищенню продуктивності праці цього покоління, яке почало працювати у 1940-1960-ті рр. Держава також здійснювала інвестиції у вищу освіту, що заохочувало вчених та інженерів до впровадження різних промислових інновацій. Наприклад, у 1936 р. був створений Національний інститут політехніки, у 1942 р. - Монтерейський інститут технологій та вищої освіти.

Неможливо оминути увагою і позитивні результати для економічного розвитку Мексики участі у Другій світовій війні. Мається на увазі підтримка союзників, що сприяла акумулюванню значних фінансових ресурсів як у державних резервах, так i в руках пересічних громадян. Мексика отримала прибуток від експорту матеріалів i сировини, необхідних у військовому виробництві США, що дозволило поповнити золотовалютні резерви країни. Ці 
кошти були використані для погашення заборгованості Мексики, субсидування імпорту харчових продуктів, початку великих інфраструктурних проектів. Прийнята США у 1942 р. програма Брасеро спрямовувалась на залучення робочої сили (унаслідок призову до армії країна відчувала катастрофічну нестачу робочих рук у сільському господарстві), переважну частину якої склали мексиканці. Ця програма була настільки успішною, що після закінчення війни понад 5 млн. мексиканців залишилося працювати у 24 штатах США [12].

Для розуміння економічних проблем Мексики та курсу, який країна обрала у повоєнний період, необхідно взяти до уваги роль латиноамериканських країн у міжнародному поділі праці (їм відводилось місце постачальника сировини). Економічна криза і депресія 1930-х рр. поставили перед Латинською Америкою питання: яким чином в умовах різкого зменшення попиту на експорт сировини регіон може сподіватися на виживання? Відповідь на це питання дали аргентинський економіст Рауль Пребіш і німецький економіст Ганс Зінгер, які прийшли до висновку, що економіки, які спеціалізуються на експорті сировинних товарів, 3 часом зіштовхнуться 3 великими проблемами. Вони обгрунтували необхідність втручання держави в економіку з метою індустріалізації розвитку. Ця ідея активно розроблялась Економічною комісією для Латинської Америки i Карибів (ECLAC) і була покладена в основу стратегій імпортозамінної індустріалізації (ISI), прийнятих у Мексиці, Бразилії, Аргентині та Чилі. Їх мета полягала у заміні промислових товарів, які раніше імпортувалися, товарами, що випускаються на внутрішньому ринку. Справа в тому, що під час війни та невдовзі після неї притік промислових товарів у Мексику суттєво скоротився (внаслідок переведення економіки на воєнні рейки європейськими країнами та США). Між тим, на мексиканському ринку на них існував великий попит, обумовлений високими для того часу заробітними платами робітників, задіяних у виготовленні експортної продукції, та накопиченням коштів у сім'ях гастарбайтерів.

У Мексиці політика імпортозамінної індустріалізації розпочалась у 1941 р. із Закону «Про виробничі галузі», прийняття якого ініціював президент Мануель Евіла Камачо, та Закону «Про розвиток нових і необхідних галузей», який вступив в дію у 1946 р. під час президентства Мігеля Алемана Вальдеса [13]. Стратегія індустріалізації країни включала такі головні напрями: заохочення, в т. ч. через податкові пільги, національних приватних капіталовкладень, захист їх від іноземних конкурентів; розширення державного сектора в промисловості шляхом націоналізації окремих підприємств і галузей, будівництва державних підприємств; збільшення державного фінансування і кредитування промисловості.

Запущена президентом Вальдесом масштабна програма імпортозаміщення стимулювала випуск промислових товарів шляхом підвищення на них внутрішнього попиту. Імпортозаміщення здійснювалося в хімічній та нафтохімічній промисловості, виробництві гуми, пластмас, мінеральних добрив, фармацевтичних препаратів, мила, миючих засобів та косметики. Унаслідок цього почала розвиватися низка галузей національної промисловості, особливо виробництво таких споживчих товарів, як одяг, невелика побутова техніка та консерви, що сприяло розвитку національного бізнесу. 3 однієї сторони, це спрямувало робочу силу до великих міст (центрів виробництва i послуг, насамперед Мехіко), а $з$ другої - сприяло зростанню споживчого попиту. Почав зростати середній клас і його роль, як в міському житті, так і в національній 
політиці. Мексиканський уряд сприяв розвитку промисловості i шляхом державного інвестування сільськогосподарської, енергетичної та транспортної інфраструктури. Після 1940 р. темпи урбанізації суттєво підвищились, що вимагало створення додаткових енергетичних потужностей, надання населенню міст доступу до питної води, зрошення сільськогосподарських територій та контролю за повенями. До 1950 р. мережа доріг Мексики збільшилася до 21 тис.км., 3 яких близько 13,6 тис. км. були збудовані. Як зазначає В.Ургуді, «інфраструктурні проекти не тільки підживлювали зростаючу промисловість, але створили у нації відчуття сучасності» [14, С. 3].

Економічна стабільність країни, високий кредитний рейтинг, зростаюча кількість освічених робітників, фінансові заощадження від війни забезпечили гарні умови для початку програми індустріалізації. Уряд запровадив контроль над імпортом споживчих товарів, однак це не торкнулося товарів промислового призначення (машин, устаткування). Їх імпорт з 1960 по 1975 рр. зріс у 3,5 рази (для порівняння - товарів широкого вжитку - удвічі) [6, С. 1160]. Підтримка мексиканських малих і середніх підприємств унаслідок незначних конкурентних переваг у порівнянні з американськими компаніями змусила уряд запровадити для обмеження імпорту високі тарифні ставки та зменшити кількість виданих ліцензій на імпорт. На це вказує динаміка імпорту, що підлягав ліцензуванню: у 1956 р.$28 \%$, у 1960 р. - $60 \%$ в у 1970 о. - 70\% [15, С. 1163].

У 1960-х рр. у Мексиці відбулось розширення державного сектору. Новий етап націоналізації промисловості, який у науковій літературі отримав назву «мексиканізаці», розпочався 3 прийняття у 1961 р. Закону «По гірничодобувну промисловість», який декларував надання нових концесій на видобуток лише компаніям, які мають 66\% національного капіталу. Низьке виробництво заліза, сталі та сірки змусило уряд також інвестувати в їх виробництво. У випадку нафтохімічної промисловості максимальний відсоток іноземного капіталу становив $40 \%$. У 1966 р. було «мексиканізовано» фінансовий сектор. У 1970 p. націоналізації зазнали підприємства чорної металургії, виробництво цементу, скла, целюлози, добрива та алюмінію - держава отримала контроль над 51\% капіталу. Цей закон не мав зворотної сили, тому іноземні компанії, які планували інвестувати у розширення виробництв або придбати нові, повинні були узгоджувати свої дії з Міністерство закордонних справ, що збільшило їх залежність від мексиканського бюрократичного апарату, який, у свою чергу, постійно збільшувався.

Найбільш швидко державний сектор зростав під час президентства Луїса Ечеверрії (1970-1976 рр.) - у цей час число державних підприємств зросло з 84 до 795. Як зазначають Тімоті Дж. Кехо і Феліпе Меза, «мексиканські підприємці були «захищені» не тільки від іноземної продукції, але і від іноземного капіталу» [16]. У подальшому це призвело до втрати конкурентоспроможності мексиканських компаній та посилення олігополістичної структури економіки країни.

Для підтримки державних підприємств, які досить часто були низькорентабельними, а також амбітних проектів соціального (розвиток інфраструктури та системи освіти) та іміджевого (Олімпіада 1968 р.) характеру уряд був змушений вдатись до зовнішніх запозичень. У цьому контексті наголосимо, що однією з умов швидкого економічного зростання Мексики стало привернення іноземного капіталу, перш за все, американського. Однак протягом 
1960-1980-х рр. ця політика зазнала суттєвих змін. У 1960-х рр. урядові кола дотримувалися думки, що краще вдаватися до зовнішніх запозичень, ніж створювати умови для привернення прямих іноземних інвестицій. Комплекс вказаних факторів зумовив поступове зростання зовнішнього боргу Мексики, який на початку 1980-х рр. досяг катастрофічних для економіки країни масштабів. Так, 3 1970 р. по 1976 р. він збільшився з \$8,63 до \$29,45 млрд. [17, С. 234-235].

Однак у короткостроковій перспективі обрана урядом стратегія розвитку країни призвела до помітного прискорення економічного зростання Мексики. У 1960-х рр. його середні темпи становили близько 7\% ВВП. Інфляція споживчих цін коливалась у межах 3-4\% на рік, курс песо з 1954 по 1976 р. був стабільним і підтримувався на рівні 12,5 за \$. Частка промисловості у структурі ВВП постійно збільшувалась: у 1950 р. - 22\%, у 1960 р. - 29\%, у 1970 р. - 30,4\%. На противагу, частка сільського господарства у загальному обсязі виробництва почала зменшуватись (відповідно 15,9\%, 12,2\%, 9\%) 1 [18, С. 3]. Мексика перетворилась 3 аграрно-індустріальної на індустріально-аграрну країну. Ця стратегія упроваджувалась президентами Адольфо Руїсом Котінесом (1952-1958 рр.), Адольфо Лопесом Матеосомі (1958-1964 рр.) та Густаво Діасом Ордасом (19641970 рр.).

До 1970 р. Мексика розширила свою експортну базу і стала в значній мірі самодостатньою у виробництві продовольства, сталі та більшості споживчих товарів. Модернізація призвела до зростання урбанізації і змін у структурі мексиканського суспільства. Почав зростати середній клас, головними представниками якого стали не лише представники робітничих професій, а і «білі комірці» - робітники сфери державного управління, соціальних послуг, фінансів, торгівлі, кількість яких швидко зростала. Для характеристики цих змін А.Е.Латапі та М.Гонзалес де ла Роша вводять терміни «новий робочий клас» та «міський середній клас». Зростання заробітної плати сприяло зменшенню співвідношення бідних домогосподарств 3 80,7\% у 1960-1970-х рр. до 52,5\% у 1980 р. [19, С. 60]. Мексика перетворилась на бажане місце для інвестицій транснаціонального капіталу. У країні впроваджувалися певні демократичні свободи (хоча розгін студентської демонстрації у 1968 р., що призвів до кривавих наслідків, дещо похитнув впевненість у цьому). Аналізуючи фактори економічного зростання Мексики у вказаний період, А.Райан вказує на вирішальну роль поєднання агресивного капіталістичного розвитку, державного протекціонізму та іноземних інвестицій, звертаючи увагу на той факт, що революція 1910 р. виробила порівняно доброякісну патерналістську форму «м'якого» авторитаризму [12].

Високі темпи економічного зростання у Мексиці у 1940-1970-х рр. дали привід деяким експертам і політикам 1960-х рр. висловити думку про мексиканське «економічне диво» [19]. На наш погляд, ця теза є досить контроверсійною, адже урядова політика окресленого періоду заклала низку економічних і соціальних проблем. Нарощування промисловості для виробництва дешевої споживчої продукції вимагало більш високого рівня імпорту засобів виробництва, зокрема фабричних машин. Отже, як би це не виглядало парадоксально, стратегія ISI, яка була покликана зменшити залежність від імпортних товарів, призвела до протилежних наслідків. Мексика недостатньо ефективно диверсифікувала структуру експорту відповідно до зміни внутрішньої економічної ситуації; загальмувалось виробництво та експорт традиційних товарів. Недостатність 
експортних надходжень для оплати потрібного імпорту та потреб державного бюджету привела до збільшення дефіциту торгових операцій і періодичних кризових ситуацій $з$ платіжним балансом, що збільшило залежність країни від зовнішніх запозичень.

Доцільно вказати i на загострення соціальних протиріч. Ставка на капіталомістке виробництво, при якому використовується велика кількість машин у поєднанні з відносно нечисленними працівниками, обмежила створення робочих місць, що враховуючи високі темпи зростання населення в країні, збільшило безробіття. Хоча загалом середній клас зростав, у суспільстві поглибилась соціальна поляризація - внаслідок застою у сільському господарстві реальні доходи селян почали падати. Не дивлячись на помірне зростання заробітної плати, внаслідок прихованої інфляції купівельна спроможність населення почала знижуватись.

Вказані тенденції призвели до того, що восени 1976 р. новий президент країни Лопес Портільо вперше за 22 роки змушений був девальвувати песо на 45\%. Країна почала невпинно скочуватися в економічну прірву. I лище світова енергетична криза, що спричинила «нафтовий» бум, тимчасово урятувала Мексику, яка в 1978 р. увійшла в числа найбільших світових експортерів нафти [20, С. 21].

Вказане дозволяє зробити висновок про суперечливість тенденцій соціальноекономічного розвитку Мексики у 1940-1970-х рр., що стало однією $з$ причин гальмування економічного зростання у наступні роки і формування боргової кризи початку 1980-х pp.

\section{Список використаних джерел та літератури}

1. Шульговский А.Ф. Мексика на крутом повороте своей истории / А. Шульговский. - М.: Просвещение, 1967. - 547 с.

2. Ковалев Е.В. Социально-политические преобразования в Мексике (1930-1960гг.) / Е.Ковалев // Вопросы истории. - 1970. - №6. - С. 32-50.

3. Ковалев Е.В. Аграрная реформа в Мексике / Е.Ковалев // Вопросы истории. - 1980. - №8. - C. 57-71.

4. Мексика: тенденции экономического и социально-политического развития / [СапрыковаСаминская Т.В., Онуфриев Ю.Г., Погорелов Ю.Ф.] - М.: Наука, 1983. - 389 с.

5. Визгунова Ю.И. Рабочий класс в освободительном движении Мексики 60-80 годы / Ю. Визгунова. - М.: Наука, 1989. - 143 с.

6. Мексика: политика. Экономика. Культура / [сборник статей / предисл. д-ра ист. наук А.Ф. Шульговского; отв.ред. А.Ф. Шульговский]. - М.: Наука, 1968. - 355 с.

7. Мексика: капитализм и общество. Противоречия развития [под ред. Е.Г.Лапшева, И.К.Шереметьва]. - М.: Наука, 1990. - 191 с.

8. Боровков А.Н., Шереметьев И.К. Мексика на новом повороте экономического и политического развития / А.Боровков, И.Шереметьев. - М.: ИЛА РАН, 1999. - 284 с.

9. Мексика: парадоксы модернизации [Бобровников А.В., Боровков А.Н, Визгунова Ю.И., Воротникова Т.А. и др.] под ред. Давыдова В.М. - М.: ИЛА РАН, 2013. - 336 с.

10. Kehoe T.J., Meza F. Catch-up Growth Followed by Stagnation: Mexico, 1950-2010 / Federal Reserve Bank of Minneapolis Research Department. Working Paper 693. Revised November 2012. - 45 p. [Electronic Resource] - Mode of Access: https://www.minneapolisfed.org/research/wp/wp693.pdf (Last Access: September 2, 2017) - Title from the Screen.

11. Бобровников А.В. Мексика сохраняет свой шанс / А.Бобровников // Латинская Америка. - 2013. - № 1. - C. 38-50.

12. Ryan A. Mexican Politics, Economy, and Society, 1946: Latin American History. Oxford research encyclopedia [Electronic Resource] - Mode of Access: 
http://latinamericanhistory.oxfordre.com/view/10.1093/acrefore/9780199366439.001.0001/acrefore-

9780199366439-e-261(Last Access: September 2, 2017) - Title from the Screen.

13. Lanis P. Before the Golden Age. Economic Growth in Mexico and Portugal, 1910-1950. The Decline of Latin American Economies: Growth, Institutions, and Crises [Electronic Resource] - Mode of Access: http://www.nber.org/chapters/c10653(Last Access: September 2, 2017) - Title from the Screen.

14. Urquidi Víctor L. The Outlook for the Mexican Economy. Pre-publication working papers of the Institute of Latin American Studies University of Texas at Austin [Electronic Resource] - Mode of Access: http://lanic.utexas.edu/project/etext/liilas/tpla/8705.pdf (Last Access: September 2, 2017) Title from the Screen.

15. Pacheco-López P. Foreign direct investment, exports and imports in Mexico /P. Pacheco-López // The World Economy. - 2005. - Vol. 28. - №8. - P. 1157-1172.

16. Pacheco-López P., Thirlwall A.P. Trade Liberalisation in Mexico: Rhetoric and Reality / Penélope Pacheco-López, A.P. Thirlwall // Journal of Post Keynesian Economics. - 2004. -Vol.29, №1 . P. 41-61.

17. Bazdresch C., Levy S. Populism and Economic Policy in Mexico, 1970-1982 / The Macroeconomics of Populism in Latin America. [Ed. Carlos Bazdresch, Santiago Levy]. - University of Chicago Press, January 1991. - P. 216 - 267.

18. Baer W. Import Substitution and Industrialization in Latin America: Experiences and Interpretations / W.Baer // Latin American Research Review. - 1972. - Vol.7. - №. 1. - P. 95-122 [Electronic Resource] - Mode of Access: http://latinamericanhistory.oxfordre.com/view/10.1093/acrefore/9780199366439.001.0001/acrefore-

9780199366439-e-261(Last Access: September 2, 2017) - Title from the Screen.

19. Latapí A.E., González de la Rocha M. Crisis, restructuring and urban poverty in Mexico / A.E.Latapí, M.González de la Rocha //Environment and Urbanization. - 1995. - Vol. 7. - № 1. - P. 5776.

20. Heath J. Mexico and the Sexenio Curse: Presidential Successions and Economic Crises in Modern Mexico / J.Health. - Washington, DC: Center for Strategic and International Studies, 1999. - 107 p.

\section{References}

1. SCHYLGOVSKIJ, A. (1967) Mexika na krytom povorote svoej istorii. Moskwa: Prosceschenije.

2. KOVALOV, E.(1970) Socialno-politicheskije preobrazovanija v Mexike (1930-1960 gg.). Voprosi istorii. №6, S.32-50.

3. KOVALOV, E. (1980) Agrarnaja reforma v Mexike. Voprosi istorii. №8, S.57-71.

4. SAPRIKOVA-SAMINSKAJA, T., ONYFRIEV, U. and POGORELOV, Y. (1983) Mexika: tendencii economicheskogo i socialno-politicheskogo pazvitija. Moskwa: Nauka.

5. VIZGYNOVA, Y. (1989) Rabochij klass v osvoboditelnom dvizhenii Mexiki 60-8- godi. Moskwa: Nauka.

6. SHYLGOVSKIY,A. (ed.) (1968) Mexika: politica. Economika. Kyltyra. Moskwa: Nauka.

7. LAPSHEV, E., SCHEREMETIEV, I. (eds.) (1990) Mexika: capitalism i obschestvo. Protivorechija razvitija. Moskwa: Nauka.

8. Borovkov A.N., Scheremetjev I.K. Mexica na novom povorote ekonomicheskogo i politicheskogo razvitija / A.N.Borovkov, I.K.Scheremetjev. - M.: ILA RAN, 1999. - $284 \mathrm{~s}$.

9. DAVIDOV, V. (ed.) (2013) Mexika: paradoksi modernizacii. Moskwa: ILA RAN.

10. KEHOE, T.J., MEZA, F. (2012) Catch-up Growth Followed by Stagnation: Mexico, 19502010. Federal Reserve Bank of Minneapolis Research Department. Working Paper 693. [Online] Avaliable from: https://www.minneapolisfed.org/research/wp/wp693.pdf (Accessed September 2, 2017).

11. BOBROVNIKOV, A. (2013) Mexica sohraniajet svoj shans. Latinskaja Amerika. N1., S.38-50.

12. RYAN, A. (2016) Mexican Politics, Economy, and Society, 1946. Latin American History. Oxford research [Online] Avyclopedia from: http://latinamericanhistory.oxfordre.com/view/10.1093/acrefore/9780199366439.001.0001/acrefore9780199366439-e-261(Accessed September 2, 2017). 
13. LANIS, P. (2007) Before the Golden Age. Economic Growth in Mexico and Portugal, 19101950. The Decline of Latin American Economies: Growth, Institutions, and Crises [Online] Avaliable from: http://www.nber.org/chapters/c10653 (Accessed September 2, 2017).

14. URQUIDI, V. L. (1987) The Outlook for the Mexican Economy. Pre-publication working papers of the Institute of Latin American Studies University of Texas at Austin [Online] Avaliable from: http://lanic.utexas.edu/project/etext/llilas/tpla/8705.pdf (Accessed September 2, 2017).

15. PACHECO-LOPEZ, P. (2005) Foreign direct investment, exports and imports in Mexico. The World Economy. Vol.28, №8, P.1157-1172.

16. PACHECO-LOPEZ, P., THIRWALL, A.P. (2004) Trade Liberalisation in Mexico: Rhetoric and Reality. Journal of Post Keynesian Economics. Vol.29, №1. P.41-61.

17. BAZDRECH, C., LEVY, S. (eds.) (1991) Populism and Economic Policy in Mexico, 19701982. The Macroeconomics of Populism in Latin America. University of Chicago Press, P.216 - 267.

18. BAER, W. (1972) Import Substitution and Industrialization in Latin Amercia: Experiences and Interpretations. Latin American Research Review. Vol.7, №. 1, P. 95-122 [Online] Avaliable from: http://latinamericanhistory.oxfordre.com/view/10.1093/acrefore/9780199366439.001.0001/acrefore9780199366439-e-261(Accessed September 2, 2017).

19. LATAPI, A.E., GONZALES DE LA ROCHA, M. (1995) Crisis, restructuring and urban poverty in Mexico. Environment and Urbanization. Vol. 7, № 1, P.57-76.

20. HEATH, J. (1999) Mexico and the Sexenio Curse: Presidential Successions and Economic Crises in Modern Mexico. Washington, DC: Center for Strategic and International Studies.

Надійшла до редколегії 18.02.2017

Tetiana Perga, PhD (History), senior researcher, State institution "Institute of World History of NAS of Ukraine", Kyiv

\section{FEATURES OF SOCIO-ECONOMIC DEVELOPMENT OF MEXICO IN 40-70 S OF THE XX CENTURY}

The economic and social policy of Mexico 1940-1970's has been investigated. The preconditions for the economic growth of Mexico shaped in the early 1930's - 1940's has been analyzed. Thus, the article touches upon the agrarian and educational reforms, the nationalization of the most important industries and the formation of the public sector, expansion of export during the World War II. The reasons of adopting the policy of import substitution industrialization and its main directions have been revealed. The promotion of national private investments, protection from foreign competitors, expansion of the public sector in industry by nationalizing certain enterprises and industries, construction of state-owned enterprises, as well as the increase of state financing and lending to industry has been explored. The positive results of Mexico's development in the 1940s-1970s have been assessed as follows: high rates of economic growth, stability of national currency, low inflation, growing of the middle class, implementation of many infrastructure and social projects. It is concluded that despite the significant short-term successes, the strategy of development of Mexican government had a number of "side effects" that led to a slowdown in economic growth over the coming years, increasing of social polarization and excessive dependence on external financing. The problems arose at that time resulted in the deep financial and economic crisis of Mexico in the early 1980 's.

Keywords: Mexico, import substitution industrialization, mexicanization of economy, agrarian reform. 